Jusuf, Jopie, 2003, Kriteria Jitu Memperoleh kredit bank, PT. Elex Media Komputindo, Jakarta.

Kasmir, 2012, Dasar-dasar Perbankan, Pradnya Paramita, Jakarta.

Muhammad, Abdulkadir, 2010, Hukum Dan Lembaga Keuangan, Alumni, Bandung

Naja, Daeng, 2005, Hukum Kredit Dan Bank Garansi, Citra Aditya Bakti, Bandung.

Padjrijah, Siti Chalimah, 2006, Cetak Biru Bank Perkreditan Rakyat, Direktorat Pengawasan Bank Perkreditan Rakyat, Bank Indonesia.

Salim H.S, 2010, Perkembangan Teori Dalam Ilmu Hukum, Rajawali Pers, Jakarta.

Sembiring, Sentosa, 2009, Hukum Perbankan, CV. Mandar Maju, Bandung.

Situmorang, Victor M. dan Sitanggang, Cormentyna, 2003, Gross Akta Dalam Pembuktian dan Eksekusi, Rineka Cipta, Jakarta.

Sjahdeini, Sutan Remi, 2009, Kebebasan Berkontrak dan Perlindungan yang Seimbang bagi Para Pihak dalam Perjanjian Kredit Bank di Indonesia, Cetakan I, Institut Bankir Indonesia, Jakarta.

Sjaifurrachman, 2011, Aspek Pertanggungjawaban Notaris Dalam Pembuatan Akta, Mandar Maju, Surabaya.

Suyatno, Thomas, 2004, Dasar-dasar Perkreditan, Edisi ketiga, PT. Gramedia Pustaka Utama, Jakarta.

Syahrani, Riduan, 2010, Seluk Beluk dan Asas-asas Hukum Perdata, Alumni, Bandung.

Untung, H. Budi, 2012, Kredit Perbankan di Indonesia, Andi, Edisi Kedua, Yogyakarta.

$* * * * *$

Acta Comitas (2017) $1: 98-110$ IS SN : 2502-8960 I e-ISSN : 2502-7573

\title{
ANALISIS YURIDIS TENTANG HAK INGKAR NOTARIS DALAM HAL PEMERIKSAAN MENURUT UNDANG-UNDANG JABATAN NOTARIS DAN KODE ETIK NOTARIS
}

oleh:

Bagus Gede Ardiartha Prabawa

Universitas Udayana Denpasar

\section{ABSTRAK}

Notaris dalam menjalankan jabatannya selaku pejabat umum, selain terkait pada suatu peraturan jabatan, juga terkait pada sumpah jabatan yang diucapkannya pada saat diangkat sebagai notaris dimana notaris wajib untuk merahasiakan isi akta dan keterangan yang diperolehnya sebagaimana diatur dalam Pasal 4 ayat (2) UUJN, Pasal 170 ayat (1) KUHAP, Pasal1909 ayat (2) KUHPerdata,Pasal 322 ayat (1) KUHPidana. Namun berdasarkan ketentuan dalam Pasal 54ayat (1) dan Pasal 66 ayat (1), terkesan seorang notaris dapat memberitahukan isi akta pada pihak yang tidak berkepentingan terhadapnya seperti pihak kepolisian asal didukung peraturan perundang-undangan. Adapun isu hokum dalam penelitian ini antara lain adalah mengenai pengaturan hak ingkar notaris dalam hal dilakukan pemeriksaan terhadap notaris berdasarkan UUJN dan Kode Etik Notaris dan mengenai penyelesaian hukumnya apabila notaris menggunakan hak ingkarnya pada saat dilakukan pemeriksaan.

Metode penelitian dalam penulisan tesis ini adalah metode penelitian hukum normatifdan Pendekatan yang digunakan dalam penelitian ini adalah pendekatan perundang-undangan (statute approach) pendekatan kasus (case approach). Selanjutnya, bahan hukum yang digunakan adalah bahan hukum primer, sekunder, dan tertier yang kemudian bahan hokum tersebut dianalisis dengan teknik analisis yuridis kualitatif.

Hasil penelitian dalam tesis ini menunjukkan bahwa pengaturan Hak ingkar terhadap jabatan notaris terdapat pada sumpah jabatan Notaris yang memerintahkan untuk merahasiakan isi akta yang diatur pada Pasal 4 dan Pasal 16 UUJN, serta Pasal 322 ayat (1) KUHP. Pasal-pasal tersebut tidak berlaku jika Undang-Undang lain memerintahkan untuk membuka rahasia dan memberikan keterangan / pernyataan tersebut kepada pihak yang memintanya. Akibat hukum bagi seorang notaris dalam menggunakan hak ingkarnya di depan pengadilan yaitunotaris harus dibebaskan dari kewajiban sebagai saksi atau memberikan kesaksian di muka pengadilan dan membebaskan notaris dari segala tuntutan dari pihak-pihak yang 
berkepentingan apabila hak ingkar tersebut di tolak oleh hakim/pengadil atau menurut ketentuan hukum ia diwajibkan memberikan kesaksian di muka pengadilan.

Kata Kunci: Hak Ingkar Notaris, Pemeriksaan, dan Kode Etik Notaris.

\title{
JURIDICAL ANALYSIS OF REFUSAL RIGHTS OF A NOTARY REGARDING EXAMINATIONS BASED ON LAWS OF HIS POSITION AND CODE ETICHS
}

\author{
by : \\ Bagus Gede Ardiartha Prabawa \\ Udayana University Denpasar
}

\section{ABSTRACT}

A notary in running his position as a public official, other than related to a regulatory office, also related to the oath of office taken at the time appointed as a notary which she / he is obliged to keep the contents of the deed and the information obtained as stipulated in Article 4 (2) UUJN Article 170 paragraph (1) Criminal Procedure Code, Article 1909 paragraph (2) of the Civil Code, Article 322 paragraph (1) of the Criminal Code. However, under the provisions of Aticle 54 paragraph (1) and Article 66 paragraph (1), impressed a notary deed can tell the content to parties having unauthorized access to it such as the police provided that it is supported by the legislation. As for the legal issues in this study, they include the setting of refusal rights of notaries in the event of examination to notaries according to UUJN and Code Ethics and the legal settlement if the notary uses his refusal rights at the time of exmination.

Research methods of this thesis were normative legal research methods and approach used in this study were statute approach and case approach. Then, legal materials used were the primary legal materials, secondary, and tertiary legal materials which were then analyzed by qualificative juridical analysis techniques.

The results of the research in this thesis showed that the arrangements of refusal rights of the notary office lies on his/her oath, ordering to keep the contents of the deed confidential as stipulated in Article 4 and Article 16 in UUJN, as well as Article 322 paragraph (1) of Criminal Code. Such articles do not apply if the other Act orders to unlock the secrets and provide information / statement to those who request it. The legal consequences for a notary in the exercise of his refusal rights in court is that a notary must be freed from the obligation as a witness or from testifying in court and freed notary from any claims of the interested parties when the refusal rights are rejected by the judge / court or by provisions of the law tha he is obliged to testify in court.

Keywords: Notary Refusal Rights, Examinations, and the Notary Code Ethics

\section{PENDAHULUAN}

\subsection{Latar Belakang Masalah}

Profesi di bidang hukum merupakan profesi luhur yang terhormat atau profesi mulia (nobile officium) dan sangat berpengaruh di dalam tatanan kenegaraan. Profesi di bidang hukum, diantaranya: Polisi, Advokat, Jaksa, Hakim, serta Notaris dan juga Pejabat Pembuat Akta Tanah (PPAT) merupakan pilar-pilar utama dalam penegakan supremasi hukum untuk menjalankan strategi pembangunan hukum nasional. Profesionalitas dan intregitas yang tinggi dari masing-masing aparat penegak hukum tersebut mutlak dibutuhkan sesuai dengan tugas pokok, fungsi dan kewenangannya masing-masing.

Profesi hukum sebagai profesi yang terhormat mempunyai nilai-nilai moral profesi yang harus ditaati oleh aparatur hukum yang menjalankan profesi tersebut, yaitu: kejujuran, bertanggung jawab, kemandirian moral, dan keberanian moral. ${ }^{1}$

Notaris sebagai salah satu pilar penegakan hukum nasional, dalam menjalankan profesinya selain harus berdasarkan pada Undang-undang, juga harus memegang teguh nilai-nilai moral profesi tersebut. Notaris merupakan profesi hukum dan dengan demikian profesi Notaris adalah suatu profesi mulia (nobile officium), hal tersebut dikarenakan profesi Notaris sangat erat hubungannya dengan kemanusiaan. Akta yang dibuat oleh notaris dapat menjadi alas hukum atas status harta benda, hak dan kewajiban seseorang. Kekeliruan atas akta Notaris dapat menyebabkan

${ }^{1}$ Abdulkadir Muhammad, 2001, Etika Profesi Hukum. PT. Citra Aditya Bakti, Bandung, hlm. 4 
tercabutnya hak seseorang atau terbebaninya seseorang atas suatu kewajiban. ${ }^{2}$

Sejalan dengan perkembangan hukum dan kebutuhan masyarakat terhadap pengguna jasa notaris, dibentuklah Undang-Undang Republik Indonesia No. 30 Tahun 2004 tentang Jabatan Notaris (selanjutnya disebut UUJN) jo. UndangUndang Nomor 2 Tahun 2014 tentang Perubahan atas Undang-Undang Nomor 30 Tahun 2004 tentang Jabatan Notaris (selanjutnya disebut UUJN-P), dengan maksud untuk menggantikan ketentuan Reglement of Het Notaris Ambt in Indonesia (S.1860 No. 3) tentang Peraturan Jabatan Notaris (untuk selanjutnya disebut PJN) yang tidak sesuai lagi dengan perkembangan hukum dan kebutuhan masyarakat. UUJN jo. UUJN-P tersebut diharapkan dapat memberikan perlindungan hukum, baik kepada masyarakat maupun terhadap notaris itu sendiri dan juga diharapkan lebih baik dari pada peraturan perundangan yang digantikannya. Dalam UUJN jo. UUJN-P tersebut telah diatur ketentuan yang berkaitan dengan hak ingkar notaris dan pengawasan terhadap pelaksanaan jabatan notaris.

Berdasarkan Pasal 1 angka 1 UUJN-P dinyatakan bahwa Notaris adalah pejabat umum yang berwenang untuk membuat akta autentik dan memiliki kewenangan lainnya sebagaimana dimaksud dalam Undang-Undang ini atau berdasarkan undang-undang lainnya. Tujuannya adalah agar akta tersebut dapat digunakan sebagai bukti yang kuat jika suatu saat terjadi perselisihan antara para pihak atau ada gugatan dari pihak lain. Jika hal ini terjadi tidak menutup kemungkinan bahwa notaris akan ikut terkait dalam persoalan tersebut.

Notaris sebagai pejabat yang berpijak pada ranah hukum (seperti halnya advokat, hakim, jaksa, polisi) membuat notaris secara langsung ataupun secara tidak langsung mempunyai hak selain membuat akta autentik, juga untuk menjaga lancarnya proses hukum yang terjadi, termasuk di dalamnya berkaitan dengan proses di peradilan, baik di dalam peradilan pidana maupun perdata. Proses peradilan yang dimaksudkan disini sangat erat kaitannya dengan pembuktian, baik pembuktian dengan tulisan dan juga pembuktian dengan kesaksian.

Pada proses peradilan pidana, di dalamnya akan terdapat proses pembuktian yang menekankan pada alat bukti yang berdasarkan Pasal 184 KUHAP, yaitu Keterangan saksi, Keterangan ahli, Surat, Petunjuk, dan juga Keterangan terdakwa. Dalam Pasal 1866 KUHPerdata, yang dapat menjadi alat bukti adalah Bukti tulisan, Bukti dengan saksi-saksi, Persangkaan, Pengakuan, Sumpah, dan Segala sesuatunya dengan mengindahkan aturan-aturan yang ditetapkan dalam KUHPerdata. Seiring perjalanan waktu, pada kasus tertentu para pihak

${ }^{2}$ Abdul Ghofur Anshori, 2009, Lembaga Kenotariatan Indonesia, Perspektif Hukum dan Etika. UII Press, Yogyakarta, hlm. 25 yang berperkara dapat diwakili oleh Pengacara, Jaksa, ataupun pihak-pihak yang bersangkutan dan pengadilan merasa perlu untuk menghadirkan notaris sebagai saksi berkaitan dengan akta yang telah dibuatnya. Dalam hal terjadi sengketa, akta autentik yang merupakan alat bukti terkuat dan terpenuh dapat memberikan sumbangan nyata bagi penyelesaian sengketa.

Keberadaan notaris sebagai saksi, jika dikaitkan dengan eksistensi jabatannya dalam bidang hukum yang mempunyai hak untuk mendukung lancarnya suatu proses hukum, termasuk juga proses peradilan, kiranya bukanlah merupakan masalah. Dengan kata lain, wajar saja bilamana notaris berperan sebagai saksi dalam suatu proses peradilan. Pada sisi lain, notaris dalam menjalankan jabatannya selaku pejabat umum, selain terkait pada suatu peraturan jabatan, juga terkait pada sumpah jabatan yang diucapkannya pada saat diangkat sebagai notaris dimana notaris wajib untuk merahasiakan isi akta dan keterangan yang diperolehnya sebagaimana diatur dalam Pasal 4 ayat (2) UUJN yang menyatakan bahwa, "saya akan merahasiakan isi akta dan keterangan yang diperoleh dalam pelaksanakan jabatan saya".

Selanjutnya dalam Pasal 16 ayat (1) huruf $\mathrm{f}$ UUJN-P dijelaskan bahwa, dalam menjalankan jabatannya, notaris berkewajiban merahasiakan segala sesuatu mengenai Akta yang dibuatnya dan segala keterangan yang diperoleh guna pembuatan Akta sesuai dengan sumpah/janji jabatan, kecuali undang-undang menentukan lain. Lebih lanjut dalam Pasal 54 ayat (1) UUJN-P dijelaskan bahwa, Notaris hanya dapat memberikan, memperlihatkan, atau memberitahukan isi Akta, Grosse Akta, Salinan Akta atau Kutipan Akta, kepada orang yang berkepentingan langsung pada Akta, ahli waris, atau orang yang memperoleh hak, kecuali ditentukan lain oleh peraturan perundangundangan.

Penggunaan hak untuk merahasiakan sesuatu yang berkaitan dengan jabatan diatur pula dalam hukum acara pidana, hukum perdata, dan Kitab Undang-Undang Hukum Pidana. Pasal 170 ayat (1) KUHAP menyatakan bahwa, mereka yang karena pekerjaan, harkat, martabat, atau juga jabatannya diwajibkan untuk menyimpan rahasia, dapat minta dibebaskan dari penggunaan hak untuk memberikan keterangan sebagai saksi, yaitu tentang hal yang dipercayakan kepadanya. Selanjutnya dalam Pasal 1909 ayat (2) KUHPerdata dinyatakan bahwa, segala siapa yang karena kedudukannya, pekerjaannya, atau jabatannya menurut undang-undang, diwajibkan merahasiakan sesuatu, namun hanyalah sematamata mengenai hal-hal yang pengetahuannya dipercayakan kepadanya sebagaimana demikian. Pasal 322 ayat (1) KUHPidana menyatakan bahwasanya, barangsiapa dengan sengaja membuka rahasia yang wajib disimpannya karena jabatan atau pencahariannya, baik yang sekarang 
maupun yang dahulu, diancam dengan pidana penjara paling lama sembilan bulan atau denda paling banyak enam ratus rupiah.

Sejak saat berlakunya UUJN jo. UUJN-P, Pengadilan Negeri tidak berwenang lagi untuk melakukan pengawasan terhadap notaris, pengawasan dilakukan oleh Menteri Hukum dan HAM sebagaimana ketentuan Pasal 67 ayat (2) UUJN, yang menyatakan bahwa dalam melaksanakan pengawasan sebagaimana dimaksud pada ayat (1) Menteri membentuk Majelis Pengawas. Pengawasan atas notaris dilakukan oleh Menteri dengan membentuk Majelis Pengawas yang terdiri dari Majelis Pengawas Pusat (MPP), Majelis Pengawas Wilayah (MPW), dan Majelis Pengawas Daerah (yang selanjutnya disebut MPD). ${ }^{3}$

Menurut Pasal 67 ayat (3) UUJN-P dinyatakan bahwa:

Majelis Pengawas sebagaimana

dimaksud pada ayat (2) berjumlah 9

(sembilan) orang, terdiri atas unsur:

a. Pemerintah sebanyak 3 (tiga) orang;

b. Organisasi Notaris sebanyak 3 (tiga) orang; dan

c. Ahli atau akademisi sebanyak 3 (tiga) orang

Dengan adanya lembaga pengawas sebagaimana yang dimaksudkan dalam UUJN jo. UUJN-P, idealnya pelaksanaan jabatan notaris dapat dilaksanakan dengan profesional, jujur, amanat, dan juga mandiri. Dengan demikian pada akhirnya dapat melayani dan membantu masyarakat dengan sepenuh hati dan mendukung kepastian hukum yang berkeadilan.

Seorang notaris dalam menjalankan pelayanannya harus berhati-hati, karena kelalaian yang dibuatnya dapat menimbulkan masalah hukum di kemudian hari sehingga notaris dapat diperhadapkan pada proses peradilan, dimana notaris harus memberikan keterangannya ataupun menyerahkan fotokopi minuta akta. Meskipun para notaris itu cenderung menolak untuk memberikan keterangan dengan berlindung pada rahasia jabatan. Pasal 66 ayat (1) UUJN-P, bahwa:

Untuk kepentingan proses peradilan, penyidik, penuntut umum, atau hakim dengan persetujuan Majelis Kehormatan Notaris berwenang:

a. Mengambil fotokopi Minuta Akta dan/atau surat-surat yang dilekatkan pada Minuta Akta atau Protokol Notaris dalam penyimpanan Notaris; dan

b. Memangil Notaris untuk hadir dalam pemeriksaan yang berkaitan

${ }^{3}$ Muhammad Ilham Arisaputra, 2012, Kewajiban Notaris Dalam Menjaga Kerahasiaan Akta Dalam Kaitannya dengan Hak Ingkar Notaris, Jurnal Perspektif, Vol. XVII No. 3, Edisi September 2012, hlm. 175 dengan Akta atau Protokol Notaris yang berada dalam penyimpanan Notaris

Berdasarkan Pasal 66 ayat (1) UUJN-P tersebut di atas, maka notaris yang telah melakukan kelalaian tidak dapat serta merta menolak untuk memberi keterangan dengan alasan rahasia jabatan, oleh karena dalam ketentuan tersebut menentukan bahwasanya untuk kepentingan proses peradilan, maka dapat dilakukan pengambilan fotokopi minuta akta dan pemanggilan notaris untuk memberi keterangan setelah memperoleh persetujuan dari Majelis Kehormatan Notaris (MKN). Dalam hal inilah sebenarnya keberadaan Majelis Kehormatan Notaris sangat strategis.

Mengingat kompleksitas tugas dan penggunaan hak notaris dalam melaksanakan tugasnya, maka mereka diperlukan untuk memperoleh perlindungan hukum, dalam hal ini standar perlindungan hukum yang baku sangat diharapkan keberadaannya. Tugas dan wewenang Majelis Kehormatan Notaris (MKN) adalah untuk memeriksa notaris sehubungan dengan permintaan penyidik, penuntut umum atau hakim untuk mengambil fotokopi minuta atau surat-surat lainnya yang dilekatkan pada minuta atau dalam protokol notaris dalam penyimpanan notaris, juga pemanggilan notaris yang berkaitan dengan akta yang dibuatnya atau dalam protokol notaris yang berada dalam penyimpanan notaris. Hasil akhir pemeriksaan adalah persetujuan atau menolak permintaan penyidik, penuntut umum atau hakim.

Adapun syarat dan tata cara pengambilan minuta akta atau fotokopi minuta akta dan pemanggilan notaris yang diatur dalam Peraturan Menteri Hukum dan Hak Asasi Manusia Republik Indonesia No. M.03.HT.03.10 Tahun 2007 tentang Pengambilan Minuta Akta dan Pemanggilan Notaris. Notaris bisa saja menolak memberikan minuta aktanya dalam proses peradilan. Namun penolakan ini tidak serta merta dikatakan bahwa notaris tidak mau bekerjasama dan membantu proses peradilan, melainkan notaris hanya melaksanakan Pasal 16 ayat (1) huruf b UUJN, yang menentukan bahwa notaris wajib menyimpan minuta akta yang berdasarkan Pasal 1 angka 13 UUJN merupakan arsip negara.

Menurut Habib Adjie bahwa, para notaris berharap mendapatkan perlindungan yang proporsional dalam menjalankan tugas-tugas jabatannya sebagai seorang notaris, setidaknya ada pemeriksaan yang adil dan transparan serta ilmiah ketika Majelis Pengawas Daerah (MPD) memeriksa notaris atas permohonan pihak kepolisian, kejaksaan, atau pun pengadilan. ${ }^{4}$

Sebagai salah satu perangkat hukum, di satu sisi notaris mempunyai hak ingkar sebagai pejabat

${ }^{4}$ Habib Adjie, 2008, Hukum Notaris Indonesia: Tafsir Tematik terhadap UU No. 30 Tahun 2004 tentang Jabatan Notaris, Alumni, Bandung, hlm. 228 
umum yang profesional dengan harus memegang sumpah jabatannya untuk tidak memberitahu isi aktanya, di sisi lain notaris harus berdiri pada kepentingan negara yang mana mengacu pada kepentingan publik guna terselesainya proses hukum dalam peradilan sehingga menghasilkan putusan yang adil, bermanfaat dan menjamin kepastian, sebagaimana yang telah diatur dalam kalimat terakhir pada Pasal 16 ayat (1) huruf $\mathrm{f}$ UUJN-P, bahwa kecuali undang-undang menentukan lain, dan kalimat terakhir Pasal 54 ayat (1) UUJN-P bahwa, kecuali ditentukan lain oleh peraturan perundang-undangan. Dalam tersebut terkesan seorang notaris bisa memberitahukan isi akta pada pihak yang tidak berkepentingan terhadapnya seperti pihak kepolisian asal didukung peraturan perundangundangan.

Salah satu contoh terjadinya pemanggilan Notaris oleh Polisi tanpa mendapat persetujuan dari Majelis Pengawas Daerah (MPD), dialami oleh salah seorang Notaris di Jakarta Selatan, Notaris tersebut menolak untuk memenuhi pemanggilan tersebut dan mengirim surat kepada Kepolisian untuk meminta persetujuan terlebih dahulu kepada MPD Jakarta Selatan, agar Kepolisian mendapat persetujuan terlebih dahulu dari MPD Jakarta Selatan, kemudian karena ditolaknya pemanggilan tersebut, Polisi mengirim surat meminta persetujuan dari MPD Jakarta Selatan, tapi MPD Jakarta Selatan tidak memberikan persetujuan agar Notaris tersebut datang memenuhi Surat Panggilan tersebut. Polisi sekali lagi melakukan pemanggilan melalui Surat Panggilan ke II, dengan ancaman bila masih juga Notaris tersebut tidak datang menghadap ke kantor Kepolisian, maka Polisi akan melakukan penangkapan dan penahanan berdasarkan ketentuan Undang-Undang Nomor 8 Tahun 1981 tentang Kitab Undang-Undang Hukum Acara Pidana/KUHAP, Pasal 7 ayat (1) huruf g, Pasal 11, Pasal 112 ayat (1) dan ayat (2), Pasal 113 KUHAP dan Pasal 1909 KUHPer serta Pasal 16 ayat (1) huruf f Undang-Undang Nomor 2 Tahun 2002 tentang Kepolisian, yang berbunyi:

Dalam rangka menyelenggarakan tugas sebagaimana dimaksud dalam Pasal 13 dan 14 di bidang proses pidana, Kepolisian Negara Republik Indonesia berwenang untuk memanggil orang untuk didengar dan diperiksa sebagai tersangka atau saksi

Akan tetapi sejak keluarnya Putusan Mahkamah Konstitusi Nomor 49/PUU-X/2012 yang mencabut Pasal 66 ayat (1), yang berbunyi:

Untuk kepentingan proses peradilan, penyidik, penuntut umum, atau hakim dengan persetujuan Majelis Pengawas Daerah berwenang:

a. mengambil fotokopi Minuta Akta dan/atau surat-surat yang dilekatkan pada Minuta Akta atau Protokol Notaris dalam penyimpanan Notaris; dan b. memanggil Notaris untuk hadir dalam pemeriksaan yang berkaitan dengan akta yang dibuatnya atau Protokol Notaris yang berada dalam penyimpanan Notaris.

Dalam hal pemanggilan kepada Notaris sebagai saksi oleh Kepolisian, Notaris tersebut harus hadir. Penggunaan hak ingkar Notaris dilakukan apabila Notaris dimintai keterangan terkait dengan isi akta yang telah dibuatnya tersebut.

\subsection{Perumusan Masalah}

Berdasarkan uraian di atas, maka dikemukakan rumusan permasalahan sebagai berikut:

1. Bagaimana pengaturan hak ingkar notaris dalam hal dilakukan pemeriksaan terhadap notaris berdasarkan Undang-Undang Jabatan Notaris dan Kode Etik Notaris?

2. Bagaimana akibat hukumnya apabila notaris menggunakan hak ingkarnya pada saat dilakukan pemeriksaan?

\subsection{Tujuan Penelitian}

\subsubsection{Tujuan Umum}

a. Penelitian ini secara umum bertujuan berupa upaya untuk mengembangkan Ilmu Hukum terkait dengan paradigma science as a process (ilmu sebagai proses), dengan paradigma ini ilmu tidak akan pernah berhenti (final) dalam penggaliannya atas kebenaran. ${ }^{5}$

b. Sebagai syarat untuk memperoleh gelar Magister Kenotariatan pada Program Studi Magister (S2) Kenotariatan Program Pascasarjana Universitas Udayana Denpasar.

\subsubsection{Tujuan Khusus}

a. Untuk mengetahui dan mengkaji pengaturan hak ingkar notaris dalam hal dilakukan pemeriksaan terhadap notaris berdasarkan Undang-Undang Jabatan Notaris dan Kode Etik Notaris

b. Untuk mengetahui dan mengkaji akibat hukumnya apabila notaris menggunakan hak ingkarnya pada saat dilakukan pemeriksaan.

\subsection{Manfaat Penelitian}

1. Memberikan bahan masukan dan sumbangan pemikiran bagi pengembangan ilmu hukum pada umumnya dan bidang Kenotariatan pada khususnya.

2. Sebagai masukan bagi Notaris maupun caloncalon Notaris, agar lebih mengerti mengenai penggunaan hak ingkar notaris pada pemeriksaan di Pengadilan.

${ }^{5}$ Program Studi Ilmu Hukum Universitas Udayana, 2013, Pedoman Penulisan Usulan Penelitian dan Tesis Hukum Normatif, Denpasar, hlm. 30. 


\subsection{Landasan Teoritis \\ 1.5.1 Konsep Hukum \\ 1.5.1.1 Pengertian Notaris}

Pasal 1 angka 1 UUJN, notaris didefinisikan sebagai pejabat umum yang berwenang untuk membuat akta autentik dan kewenangan lainnya sebagaimana dimaksud dalam undang-undang ini. Definisi yang diberikan oleh UUJN ini merujuk pada tugas dan wewenang yang dijalankan oleh notaris. Artinya notaris memiliki tugas sebagai pejabat umum dan memiliki wewenang untuk membuat akta autentik serta kewenangan lainnya yang diatur oleh UUJN. ${ }^{6}$

\subsubsection{Kedudukan Notaris Sebagai Pejabat Umum}

Mengenai kedudukan notaris sebagai pejabat umum, R. Soegondo Notodisoerjo menyatakan bahwa Lembaga Notariat telah dikenal di negara Indonesia, yaitu sejak Indonesia dijajah oleh Belanda, semula lembaga ini diperuntukkan bagi golongan Eropa terutama dalam bidang hukum perdata, yaitu Burgerlijk Wetboek. ${ }^{7}$

Ketentuan mengenai kedudukan sebagai pejabat umum dapat dilihat pada Pasal 1 angka 1 UUJN jo. UUJN-P di sana dinyatakan bahwa notaris adalah pejabat umum yang berwenang untuk membuat akta autentik. Dengan demikian ditugaskan untuk menjalankan kekuasaan pemerintah, notaris memperoleh kekuasaan tersebut dari eksekutif, artinya notaris diberi kekuasaan langsung sebagian hak dan wewenang eksekutif.

\subsubsection{Kode Etik Notaris}

Notaris dalam menjalankan tugasnya, dituntut untuk selalu berpijak pada hukum dan regulasi yang berlaku di Indonesia. Bukan hanya itu, seorang notaris juga berkewajiban untuk menjalankan tugasnya sesuai dengan etika yang sudah disepakati bersama dalam bentuk kode etik, kode etik ini membatasi tindak tanduk para notaris agar dalam menjalankan praktiknya tidak bertindak sewenang-wenang. ${ }^{8}$ Kode etik notaris ada 2 yaitu:

1. Kode etik yang diatur secara hukum dalam peraturan jabatan notaris.

2. Kode etik yang ditetapkan oleh Konggres Ikatan Notaris Indonesia (INI) 1974.

\subsubsection{Hak Ingkar Notaris}

Mengenai hak ingkar (verschoningsrecht) ini diatur dalam Pasal 1909 KUH Perdata, Pasal 146 dan Pasal 277 HIR. Pasal 1909 KUH Perdata mewajibkan setiap orang yang cakap untuk menjadi saksi, untuk memberikan kesaksian di muka pengadilan. Ketentuan ini tidak berlaku terhadap mereka, yang berdasarkan ketentuan-

${ }^{6}$ Abdul Ghofur Anshori, 2009, Op. Cit, hlm. 14

${ }^{7}$ Ibid., hlm. 1

${ }^{8}$ Ira Koesoemawati dan Yunirman Rijan, 2009, Ke Notaris, Raih Asa Sukses, Jakarta, hlm. 49-50. ketentuan perundang-undangan tidak diperbolehkan untuk berbicara, demikian juga tidak berlaku terhadap mereka yang berdasarkan Pasal 1909 ayat (2) KUH Perdata dan Pasal-pasal 146 dan 227 HIR yang disebut di atas, dapat mempergunakan haknya untuk mengundurkan diri sebagai saksi, dengan jalan menuntut penggunaan hak ingkarnya. Hak ingkar merupakan pengecualian terhadap ketentuan umum yang disebut tadi, yakni bahwa setiap orang yang dipanggil sebagai saksi, wajib memberikan kesaksian.

\subsubsection{Landasan Teori}

Teori-teori hukum yang digunakan berkaitan dengan tesis ini ada 3 (tiga) teori yang digunakan sebagai landasan teoritis dalam penelitian ini yaitu :

1. Teori Perlindungan Hukum

Tokoh dari Teori Perlindungan Hukum ini adalah Roscor Pound.

Roscoe Pound mengemukakan hukum merupakan alat rekayasa sosial (law as tool of social engginering).

2. Teori Penegakan Hukum

Menurut Soerjono Soekanto secara konsepsional inti dan arti penegakan hukum terletak pada kegiatan menyerasikan hubungan nilai-nilai yang terjabarkan di dalam kaidah-kaidah yang mantap dan mengejawantah dan sikap tindak sebagai rangkaian penjabaran nilai tahap akhir, untuk menciptakan, memelihara dan mempertahankan kedamaian pergaulan hidup.

3. Teori Kepastian Hukum

Tokoh dari Teori Kepastian Hukum ini adalah Hans Kelsen dan Gustav Radbruch. Menurut Kelsen, hukum adalah sebuah sistem norma. Norma adalah pernyataan yang menekankan aspek "seharusnya" atau das sollen, dengan menyertakan beberapa peraturan tentang apa yang harus dilakukan. Norma-norma adalah produk dan aksi manusia yang deliberatif. Undang-Undang yang berisi aturan-aturan yang bersifat umum menjadi pedoman bagi individu bertingkah laku dalam bermasyarakat, baik dalam hubungan dengan sesama individu maupun dalam hubungannya dengan masyarakat.

\subsection{Metode Penelitian}

\subsubsection{Jenis Penelitian}

Penelitian ini adalah penelitian hukum normatif, yaitu suatu proses untuk menemukan aturan hukum, prinsip-prinsip hukum, maupun doktrin-doktrin hukum guna menjawab menjawab 
isu-isu hukum yang dihadapi. ${ }^{9}$ Penelitian hukum normatif selalu mengambil isu dari hukum sebagai sistem norma yang digunakan untuk memberikan justifikasi preskriptif tentang suatu peristiwa hukum, sehingga penelitian hukum normatif menjadikan sistem norma sebagai pusat kajiannya. ${ }^{10}$ Sistem norma dalam arti yang sederhana adalah sistem kaidah atau aturan. ${ }^{11}$ Dasar dari penelitian normatif di sini adalah kekaburan norma, dimana pengaturan mengenai hak ingkar notaris itu kurang jelas atau kabur sehingga dapat menimbulkan penafsiran yang berbeda-beda.

\subsubsection{Jenis Pendekatan}

Di dalam penelitian hukum terdapat beberapa pendekatan. Dengan pendekatan tersebut peneliti akan mendapatkan informasi dari berbagai aspek mengenai isu yang sedang dicoba untuk dicari jawabnya. Pendekatan-pendekatan yang digunakan di dalam penelitian hukum adalah pendekatan undang-undang (statute approach), pendekatan kasus (case approach), pendekatan historis (historical approach), pendekatan komparatif (comparative approach), dan pendekatan konseptual (conceptual approach). ${ }^{12}$

Pendekatan undang-undang (statute approach) dilakukan dengan menelaah semua undang-undang dan regulasi yang bersangkut paut dengan isu hukum yang sedang ditangani. Pendekatan kasus (case approach) dilakukan dengan cara melakukan telaah terhadap kasuskasus yang berkaitan dengan isu yang dihadapi yang telah menjadi putusan pengadilan yang telah mempunyai kekuatan yang tetap. Pendekatan historis (historical approach) dilakukan dengan menelaah latar belakang apa yang dipelajari dan perkembangan pengaturan mengenai isu yang dihadapi. Pendekatan komparatif (comparative approach) dilakukan dengan membandingkan undang-undang suatu negara dengan undangundang dari satu atau lebih negara lain mengenai hal yang sama. Sedangkan pendekatan konseptual (conceptual approach) yaitu pendekatan yang beranjak dari pandangan-pandangan dan doktrindoktrin yang berkembang di dalam ilmu hukum. ${ }^{13}$

Pendekatan yang dipergunakan dalam penelitian ini adalah pendekatan kasus (case approach). Dalam pendekatan kasus (case approach) yang perlu dipahami oleh peneliti adalah ratio decidendi, yaitu alasan-alasan hukum yang digunakan oleh hakim untuk sampai kepada putusannya. ${ }^{14}$ Ratio decidendi dapat diketemukan

${ }^{9}$ Peter Mahmud Marzuki, 2011, Penelitian Hukum, Prenada Media Grup, Jakarta, hlm. 11

${ }^{10}$ Mukti Fajar ND dan Yulianto Achmad, 2010, Dualisme Penelitian Hukum Normatif dan Empiris, Pustaka Pelajar, Yogyakarta, hlm. 36

${ }^{11}$ Ranuhandoko, 2003, Terminologi Hukum, Grafika, Jakarta, hlm. 419

${ }^{12}$ Peter Mahmud Marzuki, 2011, Op. Cit, hlm. 93

${ }^{13}$ Ibid, hlm. 93-95

${ }^{14}$ Ibid, hlm. 119 dengan memperhatikan fakta material. Faktafakta tersebut berupa orang, tempat, waktu dan segala yang menyertainya asalkan tidak terbukti sebaliknya. Perlunya fakta materiil tersebut diperhatikan karena baik hakim maupun para pihak akan mencari aturan hukum yang tepat untuk dapat diterapkan kepada fakta tersebut. ${ }^{15}$

\subsubsection{Sumber Bahan Hukum}

a. Bahan hukum primer, yaitu bahan hukum yang bersifat autoritatif ${ }^{16}$ yang terdiri dari:

1) Undang-Undang Dasar Negara Republik Indonesia Tahun 1945

2) Kitab Undang-Undang Hukum Perdata (KUH Perdata)

3) Kitab Undang-Undang Hukum Acara Pidana (KUHAP)

4) Undang Nomor 30 Tahun 2004 tentang Jabatan Notaris

5) Undang-Undang Nomor 2 Tahun 2014 tentang Perubahan atas Undang-Undang Nomor 30 Tahun 2004 tentang Jabatan Notaris

6) Peraturan perundang-undangan lainnya yang berkaitan dengan penelitian ini.

b. Bahan hukum sekunder, adalah bahan-bahan hukum yang memberikan penjelasan dan petunjuk terhadap bahan hukum primer, yang terdiri dari: berbagai literatur/buku-buku, berbagai hasil seminar, lokakarya, simposium dan penelitian, jurnal, artikel yang berkaitan dengan permasalahan dalam penelitian ini.

c. Bahan hukum tertier, adalah bahanbahan hukum yang akan memberikan petunjuk maupun penjelasan terhadap bahan hukum primer dan bahan hukum sekunder, yang terdiri dari:

1) Kamus hukum;

2) Kamus Inggris-Indonesia;

3) Kamus Umum Bahasa Indonesia;

4) Ensiklopedi.

\subsubsection{Teknik Pengumpulan Bahan Hukum}

Teknik pengumpulan bahan hukum dalam penelitian ini dilakukan dengan cara studi dokumen, yaitu dengan cara mempelajari, mengkaji dan menelaah bahan-bahan hukum yang berkaitan dengan penelitian ini.

\subsubsection{Teknik Analisis Bahan Hukum}

Bahan hukum yang telah dikumpulkan dan disistematisir kemudian dilakukan analisis secara kualitatif. Dengan kata lain, teknik analisis yang dipergunakan dalam penelitian ini adalah yuridis kualitatif dengan langkah-langkah sebagai berikut:

${ }^{15}$ Ibid
${ }^{16}$ Ibid, hlm. 142


a. Bahan hukum yang diperoleh dari penelitian diklasifikasikan sesuai dengan permasalahan dalam penelitian;

b. Hasil klasifikasi data selanjutnya disistematisasikan;

c. Bahan hukum yang telah disistematisasikan kemudian dievaluasi, diberikan argumentasi, dan dianalisis untuk dijadikan dasar dalam pengambilan kesimpulan terhadap permasalahan yang dikaji dalam penelitian ini.

\section{TINJAUAN UMUM TENTANG NOTARIS DAN HAK INGKAR NOTARIS}

\subsection{Tinjauan Umum tentang Notaris}

\subsubsection{Notaris Sebagai Pejabat Umum} dan Bukan Pegawai Negeri

Notaris adalah Pejabat Umum dan Bukan Pegawai Negeri. Istilah Notaris berasal dari kata Latin, yaitu "Notarius", yang artinya adalah orang yang membuat catatan. ${ }^{17}$ Ada juga orang yang mengatakan bahwa istilah "Notarius" itu berasal dari kata "Nota Literaria", yang artinya adalah tanda (letter mark atau karakter) yang menyatakan sesuatu perkataan. ${ }^{18}$

Pegawai Negeri menurut Undang-Undang tentang Pokok-pokok Kepegawaian adalah mereka yang setelah memenuhi syarat-syarat yang ditentukan dalam peraturan perundangundangan yang berlaku, diangkat oleh pejabat yang berwenang dan diserahi tugas Negara lainnya yang ditetapkan berdasarkan sesuatu peraturan perundang-undangan dan diberi gaji menurut peraturan perundang-undangan yang berlaku. Sedangkan Hoge Raad (H.R.) dalam Arrest Tanggal 30 Januari 1911 mengatakan bahwa Pegawai Negeri adalah mereka yang diangkat oleh penguasa untuk kepentingan/kegunaan dari setiap orang atau mereka yang bekerja pada badan publik, misalnya Negara, propinsi atau kotapradja, yang mewakilan badan itu di dalam menjalankan tugasnya dan menjalankan kekuasaan yang ada pada badan itu. Jadi, Notaris adalah Pejabat Umum tapi bukan Pegawai Negeri; Notaris tidak digaji oleh Negara; Notaris mendapatkan bayaran/honor atau hasil dari anggota masyarakat yang membutuhkan jasanya; Notaris dijadikan Pejabat Umum adalah untuk memenuhi ketentuan undang-undang dan berhubungan dengan definisi akta autentik, sebagaimana disebutkan dalam Pasal 1868 KUHPer.

\subsubsection{Tugas dan Kewenangan Notaris}

${ }^{17}$ R. Soesanto, 1982, Tugas, Kewajiban dan Hak-hak Notaris, Wakil Notaris (Sementara), Pradnya Paramita, Jakarta, hlm.34

${ }_{18}$ R. Soegondo Notodisoerjo, 1982, Hukum Notariat di Indonesia Suatu Penjelasan, CV Rajwali, Jakarta, hlm.13
Notaris $^{19}$ adalah Pejabat Umum yang diangkat dan diberhentikan oleh Pemerintah melalui Menteri, diberi tugas dan wewenang untuk membuat akta autentik mengenai semua perbuatan, perjanjian, dan ketetapan yang diharuskan oleh peraturan perundang-undangan dan/atau yang dikehendaki oleh yang berkepentingan untuk dinyatakan dalam akta autentik, menjamin kepastian tanggal pembuatan akta, menyimpan akta, menyimpan grosse, ${ }^{20}$ salinan dan kutipan akta, semua itu sepanjang pembuatan akta itu tidak juga ditugaskan atau dikecualikan kepada pejabat lain atau orang lain yang ditetapkan oleh undang-undang.

Selain itu, menurut isi ketentuan Pasal 15 ayat (2) UUJN, Notaris juga berwenang mengesahkan tanda-tangan dan memastikan tanggal surat dibawah tangan dengan mendaftar dalam buku khusus; membukukan surat-surat dibawah tangan dengan mendaftar dalam buku khusus; memuat kopi dari asli surat-surat dibawah tangan berupa salinan yang memuat uraian sebagaimana ditulis dan digambarkan dalam surat yang bersangkutan; melakukan pengesahan kecocokan fotokopi dengan surat aslinya; memberikan penyuluhan hukum sehubungan dengan pembuatan akta; membuat akta yang berkaitan dengan pertanahan; atau membuat akta risalah lelang. Demikian juga, bila ada perintah undang-undang atau peraturan perundangundangan lain yang menentukan mengenai kewenangan Notaris, maka Notaris juga berwenang untuk itu, misalnya ada ketentuan peraturan dari Menteri Koperasi, yang membolehkan Notaris untuk membuat akta Koperasi; atau peraturan dari Badan Pengawas Pasar Modal yang membolehkan Notaris yang telah mengikuti pendidikan dan dinyatakan diterima oleh Badan Pengawas Pasar Modal menjadi Penunjang Pasar Modal, sehingga Notaris tersebut dapat membuat akta-akta autentik bagi perusahaan yang sudah go public seperti pembuatan Risalah Rapat atau Berita Acara Rapat Umum Pemegang Saham tahunan suatu Perseroan Terbatas Terbuka/Tbk. di lingkungan Pasar Modal.

\subsubsection{Kewajiban Notaris}

Notaris sebagai Pejabat Umum dalam menjalankan jabatannya mempunyai kewajiban yang ditentukan dalam hukum. Pasal 16 ayat (1) UUJN mengatakan: bahwa Notaris itu harus bertindak jujur, seksama, mandiri dan tidak berpihak serta menjaga kepentingan pihak yang

${ }^{19}$ Indonesia, Undang-Undang No 30 Tahun 2004 tentang Jabatan Notaris (Lembaran Negara Republik Indonesia Tahun 2004 Nomor 117, Tambahan Lembaran Negara Republik Indonesia Nomor 4432), Pasal 15

20 Grosse adalah salinan akta pengakuan utang yang dibagian kepala aktanya berbunyi "DEMI KEADILAN BERDASARKAN KETUHANAN YANG MAHA ESA" dan mempunyai kekuatan eksekutorial 
terkait dalam perbuatan hukum; membuat akta dalam bentuk Minuta Akta dan menyimpannya sebagai bagian dari Protokol Notaris; mengeluarkan Grosse Akta, Salinan Akta, atau Kutipan Akta berdasarkan Minuta Akta; memberikan pelayanan sesuai dengan ketentuan dalam undang-undang ini, kecuali ada alasan untuk menolaknya; merahasiakan segala sesuatu mengenai akta yang dibuatnya dan segala keterangan yang diperoleh guna pembuatan akta sesuai dengan sumpah/janji jabatan, kecuali undang-undang menentukan lain; menjilid akta yangdibuatnya dalam 1 (satu) bulan menjadi buku yang memuat tidak lebih dari 50 (lima puluh) akta, dan jika jumlah akta tidak dapat dalam satu buku, dan mencatat jumlah minuta akta, bulan, dan tahun pembuatannnya pada sampul setiap buku; membuat daftar dari akta protes terhadap tidak dibayar atau tidak diterimanya surat berharga; membuat daftar akta yang berkenaan dengan wasiat menurut urutan waktu pembuatan akta setiap bulan; mengirimkan daftar akta atau daftar nihil yang berkenaan dengan wasiat ke Daftar Pusat Wasiat Departemen, yang tugas dan tanggung jawabnya dibidang ke-notariat-an dalam waktu 5 (lima) hari pada minggu pertama setiap bulan berikutnya; mencatat dalam repertorium tanggal pengiriman daftar wasiat pada setiap akhir bulan; mempunya cap/stempel yang memuat lambing Negara Republik Indonesia dan pada ruang yang melingkarinya dituliskan nama, jabatan, dan tempat kedudukan yang bersangkutan; membacakan akta dihadapan penghadap dengan dihadiri oleh paling sedikit oleh 2 (dua) orang saksi dan ditandatangani pada saat itu juga oleh penghadap, saksi dan Notaris. Namun untuk menyimpan Minuta Akta sebagaimana ditentukan dalam ayat (1) tersebut tidaklah berlaku, jika Notaris mengeluarkan akta dalam bentuk originali.

\subsubsection{Akta Notaris/Akta Autentik}

\subsubsection{Pengertian Akta Autentik}

Menurut Veegens Oppenheim Polak, akta adalah suatu tulisan dibuat untuk dipergunakan sebagai bukti. Arti akta di atas maksudnya tidak jauh berbeda yaitu bahwa akta adalah tulisan/surat yang sengaja dibuat sebagai alat bukti. ${ }^{21}$

\subsubsection{Akta Notaris sebagai Akta} Autentik

Suatu akta autentik pada dasarnya mengandung 3 (tiga) macam kekuatan pembuktian, yaitu: ${ }^{22}$

1. Kekuatan pembuktian formil, yang berarti membuktikan antara para pihak bahwa mereka telah menerangkan apa yang ditulis dalam akta tersebut.

${ }^{21}$ Veegens-Oppenheim-Polak dalam Tan Thong Kie, 2007, Serba-Serbi Praktek Notariat, Alumni, Bandung, hlm. 12

${ }^{22}$ Subekti, 2006, Pembuktian dan Daluwarsa, Intermasa, Jakarta, hlm. 68
2. Kekuatan pembuktian materiil, yang berarti membuktikan antara para pihak, bahwa benar peristiwa yang tersebut dalam akta tersebut telah terjadi.

3. Kekuatan pembuktian keluar, yang berarti disamping sebagai pembuktian antara mereka juga terdapat pihak ketiga di mana pada tanggal, bulan, dan tahun yang tersebut dalam tersebut telah menghadap kepada pegawai menerangkan apa yang terdapat dalam akta tersebut.

\subsubsection{Keabsahan Akta Notaris sebagai Akta Autentik}

Pasal 1868 BW merupakan sumber untuk otensitas akta Notaris juga merupakan dasar legalitas eksistensi akta Notaris, dengan syaratsyarat sebagai berikut:

1. Akta itu harus dibuat oleh (door) atau di hadapan (ten overstaan), seorang Pejabat Umum. Pasal 38 UU perubahan atas UUJN yang mengatur mengenai sifat dan bentuk akta tidak menentukan mengenai sifat akta. $\begin{array}{lllll}\text { Dalam Pasal } 1 & \text { angka } & 7 & \text { UU }\end{array}$ Perubahan atas UUJN menentukan bahwa akta notaris adalah akta autentik yang dibuat dihadapan Notaris menurut bentuk dan tatacara yang ditetapkan dalam UUJN, dan secara tersirat dalam Pasal 58 ayat (2) UU perubahan atas UUJN disebutan bahwa Notaris wajib membuat naskah akta dan mencatat semua akta yang dibuat oleh atau dihadapan Notaris.

2. Akta itu harus dibuat dalam bentuk yang ditentukan oleh undangundang. Setelah lahirnya UU perubahan atas UUJN keberadaan akta notaris mendapat pengukuhan karena bentuknya ditentukan oleh Undang-undang, dalam hal ini ditentukan dalam Pasal 38 UU perubahan atas UUJN.

3. Pejabat Umum oleh atau di hadapan siapa akta itu dibuat, harus mempunyai wewenang untuk membuat akta tersebut. Pasal $15 \mathrm{UU}$ perubahan atas UUJN telah menentukan wewenang Notaris. Wewenang ini merupakan suatu batasan, bahwa Notaris tidak boleh melakukan suatu tindakan diluar wewenang tersebut.

\subsubsection{Majelis Pengawas}

Ketentuan Pasal 67 UUJN sampai dengan Pasal 81 UUJN mengatur mengenai Majelis Pengawas yang bertugas untuk mengawasi pelaksanaan jabatan Notaris, yang terdiri dari: 
1. Majelis Pengawas Pusat (MPP) MPP dibentuk dan berkedudukan di ibukota negara, yang berwenang memanggil Notaris untuk di-sidang dan memberikan sanksi kepada Notaris yang melanggar pada tingkat banding. Selanjutnya MPP wajib menyampaikan laporan kepada Menteri terkait dengan keputusan yang dibuat dan diteruskan kepada MPW dan MPD serta organisasi Notaris;

2. Majelis Pengawas Wilayah (MPW)

Tugas dan wewenang MPW terbatas pada tingkat wilayah atau ibukota propinsi. Adapun tugas utama MPW adalah memeriksa dan mengambil keputusan atas laporan masyarakat. Keputusan teguran dari MPW bersifat final tetapi untuk skorsing dan pemecatan dapat diajukan banding.

3. Majelis Pengawas Daerah (MPD)

MPD mempunyai tugas pengawasan di tingkat Kabupaten atau Kota, sebagaimana wewenang dan kewajiban MPP dan MPW. MPD berwenang pula menyelenggarakan sidang dan pemeriksaan terhadap Notaris yang diduga melanggar Kode Etik Notaris dengan kewajiban untuk menyampaikan laporan kepada MPW.

2.2 Tinjauan Umum tentang Hak Ingkar Notaris

\subsubsection{Kewajiban Notaris Untuk} Merahasiakan Akta

Notaris sebagai Pejabat Umum dalam menjalankan profesi dan jabatannya untuk memberikan pelayanan hukum kepada masyarakat, mempunyai kewajiban yang ditentukan dalam Undang-Undang demi tercapainya perlindungan dan kepastian hukum,hukum, antara lain:

1. Pasal 4 ayat (2) UUJN dalam alinea ke 4 memuat Sumpah Jabatan Notaris mengenai kewajiban Notaris untuk merahasiakan isi akta

2. Pasal 16 ayat (1) UUJN mengatur kewajiban Notaris dalam menjalankan jabatannya

3. Pasal 54 UUJN yang mengatur mengenai Grosse Akta, Salinan Akta dan Kutipan Akta

4. Pasal 322 ayat (1) KUHP yang mengatur mengenai sanksi pidana terhadap orang yang wajib merahasiakan sesuatu tetapi dibukanya rahasia tersebut,

\subsubsection{Hak Ingkar Notaris}

Istilah hak ingkar ini merupakan terjemahan dari verschonningsrecht, yang artinya adalah hak untuk dibebaskan dari memberikan keterangan sebagai saksi dalam suatu perkara perdata maupun pidana. Hak ini merupakan pengecualian dari prinsip umum bahwa setiap orang yang dipanggil sebagai saksi wajib memberikan kesaksian itu.

\section{PENGATURAN HAK INGKAR NOTARIS DALAM HAL DILAKUKAN PEMERIKSAAN TERHADAP NOTARIS BERDASARKAN UNDANG- UNDANG JABATAN NOTARIS DAN KODE ETIK NOTARIS}

3.1 Pengaturan Hak Ingkar Notaris Dalam Hal Dilakukan Pemeriksaan Terhadap Notaris

Notaris sebagai Pejabat Umum diberikan perlindungan hukum oleh Undang-Undang dalam rangka memberikan kesaksian di pengadilan. Perlindungan hukum yang diberikan itu adalah Hak Ingkar, yaitu hak untuk menolak untuk memberikan kesaksian di pengadilan. Penolakan itu tidak terbatas terhadap hal yang tercantum dalam akta yang dibuatnya, tetapi keseluruhan fakta yang terkait dengan akta tersebut. Hak tersebut tidak hanya terbatas pada hak tersebut, tetapi merupakan suatu kewajiban untuk tidak berbicara. Pada praktiknya, masih sedikit Notaris yang dapat menggunakan Hak Ingkar ini, yang menentukan sah atau tidaknya alasan untuk dibebaskan dari memberikan kesaksian bagi Notaris. Pembebasan dari kewajiban untuk merahasiakan isi akta ini juga tidak merupakan alasan bagi mereka untuk begitu saja melepaskan hak mereka untuk mempergunakan Hak Ingkar. Hal ini disebabkan karena Hak Ingkar ini diberikan juga untuk kepentingan umum, sehingga tidak begitu saja dapat dikesampingkan.

\subsection{Kewajiban Notaris Dalam Menjaga Kerahasiaan Akta Dalam Kaitannya Dengan Hak Ingkar Notaris}

Pasal 4 ayat (2) UUJN mewajibkan notaris untuk tidak bicara, artinya notaris tidak diperbolehkan untuk memberikan keterangan mengenai apa yang dimuat dalam akta yang dibuatnya dan segala keterangan yang diperoleh dalam pelaksanaan jabatan, akan tetapi berdasarkan Pasal 16 ayat (1) huruf e jo Pasal 54 UUJN, penggunaan hak untuk merahasiakan isi akta tersebut bersamaan dengan penggunaan hak untuk bisa memberikan kesaksian manakala ada undang-undangnya, dengan kata lain notaris ada penggunaan hak untuk bicara. Dengan demikian notaris harus bisa membatasi diri kapan harus bicara dan kapan tidak boleh bicara, notaris tidak bisa menolak manakala dijadikan saksi dengan persetujuan MPD, sesuai dengan ketentuan Pasal 66 UUJN. Apabila peraturan yang bersangkutan secara tegas menentukan bahwa notaris wajib untuk memberikan kesaksian atau untuk memperlihatkan, maka khusus untuk keperluan itu ia dibebaskan dari sumpah dan rahasia jabatan. 
IV AKIBAT HUKUM APABILA NOTARIS MENGGUNAKAN HAK INGKARNYA PADA SAAT DILAKUKAN PEMERIKSAAN

4.1 Perlindungan Hukum Bagi Notaris Menurut Undang-Undang Nomor 2 Tahun 2014

Perlindungan hukum tersebut semata-mata bukan digunakan dalam artian bahwa Notaris adalah jabatan yang kebal hukum, akan tetapi perlindungan hukum tersebut untuk profesionalitas Notaris. Terutama untuk menjaga kepentingan peng-hadap yang telah dituangkan dalam akta autentik, di mana akta tersebut akan menjadi sebuah arsip negara yang patut dilindungi.

Mekanisme perlindungan bagi Notaris dalam ancaman pemanggilan dalam proses peradilan hingga pengambilan minuta akta dan protokol Notaris, diatur dalam Pasal 66 ayat (1) BAB VIII tentang Pengambilan Minuta akta dan Pemanggilan Notaris. Pasal tersebut berbunyi:

(1) Untuk kepentingan proses peradilan, penyidik, penuntut umum, atau hakim dengan persetujuan Majelis Pengawas Daerah berwenang

a. Mengambil fotokopi Minuta akta/dan atau surat-surat yang dilekatkan pada minuta akta atau protokol Notaris dalam pen yimpanan Notaris;

b. Memanggil Notaris untuk hadir dalam pemeriksaan yang berkaitan dengan akta yang dibuatnya atau protokol Notaris yang berada dalam penyim-panan Notaris.

\subsection{Akibat Hukum Apabila Notaris Menggunakan Hak Ingkarnya}

Dalam hal memberikan kesaksian notaris mempunyai hak untuk tidak bicara sekalipun di muka pengadilan sepanjang tidak bertentangan dengan peraturan perundang-undangan lain. Artinya, seorang notaris tidak dapat mengungkapkan akta yang dibuatnya baik sebagian maupun keseluruhannya kepada pihak lain, hal ini sesuai dengan Pasal 54 UUJN Tahun 2004 karena sebagai seorang kepercayaan, notaris berkewajiban untuk merahasiakan semua hal yang diberitahukan kepadanya dalam jabatannya sebagai notaris, dan sesuai Pasal 66 ayat (1) huruf a UUJN Tahun 2004 untuk kepentingan proses peradilan, penyidik, penuntut umum, atau hakim hanya dapat mengambil fotokopi minuta akta dan/atau surat-surat yang dilekatkan pada minuta akta atau protokol notaris dalam penyimpanan notaris dan dalam pengambilan fotokopi minuta akta atau surat-surat sebagaimana dimaksud pada ayat (1) huruf a, wajib dibuat berita acara penyerahan.
Akibat hukum bagi seorang notaris dalam menggunakan hak diamnya di depan pengadilan yaitu, pertama bahwa notaris harus dibebaskan dari kewajiban sebagai saksi atau memberikan kesaksian di muka pengadilan, apabila ia menggunakan hak ingkar. Karena secara hukum, kesaksian yang akan diberikan tersebut menurut pengetahuannya dinilai bertentangan dengan sumpah jabatan atau melanggar rahasia jabatan. Kedua membebaskan notaris dari segala tuntutan hukum dari pihak-pihak yang berkepentingan, apabila hak ingkar tersebut ternyata di tolak oleh hakim/pengadil atau menurut ketentuan hukum ia diwajibkan memberikan kesaksian di muka pengadilan.

\section{PENUTUP \\ 5.1 Simpulan}

1. Pengaturan Hak ingkar terhadap jabatan notaris terdapat pada sumpah jabatan Notaris yang memerintahkan untuk merahasiakan isi akta yang diatur pada Pasal 4 dan Pasal 16 huruf $\mathrm{f}$ Undang-Undang Nomor 2 Tahun 2014 Tentang Perubahan Atas Undang-Undang Nomor 30 Tahun 2004, hal tersebut juga diatur pada Pasal 322 ayat (1) KUHP. Kedua Pasal tersebut tidak berlaku jika Undang-Undang lain memerintahkan untuk membuka rahasia dan memberikan keterangan/pernyataan tersebut kepada pihak yang memintanya.

Berdasarkan pada Pasal 16 ayat (1) huruf e dan Pasal 54 UUJN, pada kalimat terakhir tertulis “...kecuali Undang Undang menentukan lain.” Hak ingkar notaris yang diatur dalam UUJN tidak mutlak, mengingat masih dimungkinkan bila undang-undang lain memerintahkan. Dengan demikian Notaris tidak dapat menggunakan Hak Ingkarnya jika akta yang dibuatnya berkaitan dengan:

a. Tindak Pidana Korupsi (UU Nomor 31 Tahun 1999 yang telah dirubah dengan UU Nomor 20 Tahun 2001 tentang Pemberantasan Tindak Pidana Korupsi)

b. Pelanggaran Pajak (UU Nomor 14 Tahun 2002 tentang Pengadilan Pajak).

Apabila pernyataan-pernyataan yang diajukan kepada Notaris adalah tentang apakah benar akta yang menjadi sengketa tersebut dibuat oleh Notaris yang bersangkutan dan apakah benar para pihak di dalam akta tersebut adalah benar orang yang dimaksud atau menyangkut isi akta, maka untuk itu, sudah selayaknya Notaris menggunakan Hak Ingkarnya. Hal ini didasarkan pada:

a. Notaris berhak menggunakan Hak Ingkar sesuai dengan peraturan perundang-undangan, baik perdata maupun pidana, dan tidak ada yang dapat memaksa Notaris membuka rahasia jabatannya tanpa ada suatu alasan yang jelas. 
b. Akta yang dibuat oleh dan/atau di hadapan Notaris merupakan suatu alat bukti yang sempurna, karena menerangkan segala hal yang dinyatakan oleh para pihak, sehingga memiliki kekuatan pembuktian sempurna sebagaimana diatur dalam Pasal 1870 KUHPerdata

2. Akibat hukum bagi seorang notaris dalam menggunakan hak ingkarnya di depan pengadilan yaitu, pertama bahwa notaris harus dibebaskan dari kewajiban sebagai saksi atau memberikan kesaksian di muka pengadilan, apabila ia menggunakan hak ingkar. Karena secara hukum, kesaksian yang akan diberikan tersebut menurut pengetahuannya dinilai bertentangan dengan sumpah jabatan atau melanggar rahasia jabatan. Kedua membebaskan notaris dari segala tuntutan hukum dari pihak-pihak yang berkepentingan, apabila hak ingkar tersebut ternyata di tolak oleh hakim/pengadil atau menurut ketentuan hukum ia diwajibkan memberikan kesaksian di muka pengadilan.

Penggunaan Hak Ingkar tersebut ketika Notaris sebagai saksi dalam persidangan pengadilan tidak bersifat serta merta, artinya langsung berlaku. Tapi jika notaris akan mempergunakan hak ingkarnya, wajib datang dan memenuhi panggilan tersebut dan wajib membuat surat permohonan kepada hakim yang mengadili/memeriksa perkara tersebut, bahwa Notaris akan menggunakan Hak Ingkarnya. Atas permohonan Notaris, Hakim yang memeriksa perkara yang bersangkutan akan menetapkan apakah mengabulkan atau menolak permohonan Notaris tersebut.

Jika hakim mengabulkan permohonan Notaris tersebut, maka notaris tidak perlu bersaksi. Tapi jika hakim menolak permohonan Notaris tersebut, maka Notaris perlu bersaksi. Dan atas keterangan Notaris sebagai saksi di pengadilan, jika ada yang dirugikan atas keterangan Notaris, maka Notaris tidak dapat dituntut berdasarkan Pasal 322 ayat (1) KUHP karena Notaris melakukannya atas perintah hakim.

Hak ingkar notaris hanya dapat dilakukan untuk hal-hal sebagai berikut:

a. Hubungan keluarga yang sangat dekat;

b. Bahaya dikenakan hukuman pidana;

c. Kedudukan, pekerjaan dan rahasia jabatan.

\subsection{Saran}

1. Setelah keluarnya putusan $\mathrm{MK}$ Nomor 49/PUU-X/2012 tertanggal 28 Mei 2013 yang menghapus kalimat "dengan persetujuan Majelis Pengawas Daerah" pada pasal 66 ayat (1) UUJN tahun 2004 sebaiknya segera merancang dan melaksanakan undang-undang yang secara khusus melindungi notaris dalam menjalankan tugasnya dan membuat penyidik mampu menjalankan tugasnya sebagai penyidik tanpa harus merasa bahwa profesi notaris ini "kebal hukum" sehingga tercipta suasana kondusif, adil, dan aman dalam penegakan keadilan di Indonesia.

2. Notaris dalam menjalankan tugasnya hendaknya tetap menjaga harkat dan martabat jabatan notaris sebaiknya para notaris meningkatkan profesionalisme notaris serta harkat dan martabat jabatan notaris dengan bekerja baik, tertib dan jujur serta sesuai aturan yang berlaku dan juga meningkatkan kekuatan lembaga organisasi Ikatan Notaris Indonesia (INI) sebagi satu-satunya perkumpulan notaris dan sering mengadakan seminar-seminar buat anggotanya yang membicarakan tentang aturan-aturan hukum yang berhubungan dengan tugas jabatan notaris

\section{DAFTAR PUSTAKA}

Abdul Ghofur Anshori, 2009, Lembaga Kenotariatan Indonesia, Perspektif Hukum dan Etika. UII Press, Yogyakarta

Abdulkadir Muhammad, 2001, Etika Profesi Hukum. PT. Citra Aditya Bakti, Bandung Habib Adjie, 2008, Hukum Notaris Indonesia: Tafsir Tematik terhadap UU No. 30 Tahun 2004 tentang Jabatan Notaris, Alumni, Bandung

Muhammad Ilham Arisaputra, 2012, Kewajiban Notaris Dalam Menjaga Kerahasiaan Akta Dalam Kaitannya dengan Hak Ingkar Notaris, Jurnal Perspektif, Vol. XVII No. 3, Edisi September 2012

Mukti Fajar ND dan Yulianto Achmad, 2010, Dualisme Penelitian Hukum Normatif dan Empiris, Pustaka Pelajar, Yogyakarta

Munir Fuady, 2006, Teori Hukum Pembuktian (Pidana dan Perdata), Citra Aditnya Bakti, Bandung

Peter Mahmud Marzuki, 2011, Penelitian Hukum, Prenada Media Grup, Jakarta

Purwoto Ganda Subrata, 2005, Peranan Notaris Sebagai Pejabat Umum Di Dalam Mengisi dan Turut Mensukseskan Pembangunan Nasional di Bidang Hukum, Renungan Hukum 
R. Soesilo, 1995, Kitab Undang-Undang Hukum Pidana: Serta Komentarkomentarnya Lengkap Pasal Demi Pasal, Politeia, Bogor

Ranuhandoko, 2003, Terminologi Hukum, Grafika, Jakarta

Sigid Riyanto, 2015, Tindak Pidana Tertentu Yang Terkait Dengan Notaris dan PPAT, Magister Kenotariatan Universitas Gadjah Mada, Yogyakarta

Syafran Sofyan, 2015, Perlindungan Hukum Profesi PPAT-Notaris, Makalah pada Seminar Nasional: Perlindungan Hukum Terhadap Notaris Lampu Merah Oleh Majelis Kehormatan Notaris di Magister Kenotariatan FH Universitas Diponegoro 6 Juni 2015, Semarang

$* * * * *$

Acta Comitas (2017) $1: 110-121$

ISSN : 2502-8960 I e-ISSN : 2502-7573

\title{
SANKSI HUKUM TERHADAP NOTARIS YANG MELANGGAR KEWAJIBAN DAN LARANGAN UNDANG-UNDANG JABATAN NOTARIS \\ Oleh
}

\author{
Mardiyah*, Prof.Dr.I Ketut Rai Setiabudhi, SH., MS.**, \\ Dr.Gde Made Swardhana, SH., MH. ***
}

Mahasiswi Program Magister Kenotariatan Universitas Udayana e-mail: nadinediyah@yahoo.com

\section{$A B S T R A C T$ \\ LEGAL SANCTIONS TO NOTARY VIOLATING OBLIGATIONS AND PROHIBITION UNDER THE LAW ON NOTARY FUNCTION.}

Law Number 2 of 2014 on Notary Function (UUJN) governs on Civil and Administrative sanctions to Notary violating obligations and prohibition as set forth in Article 16 and 17 of UUJN, however criminal sanction is not governed in the UUJN, therefore the application of criminal sanction itself has not been able to be imposed to a Notary violating the obligations and prohibitions of UUJN. And there is no arrangement to the mechanism of civil sanction imposition related to the cancellation of deed in the event of the authentic deed in the UUJN. Based on the background, the problems arising, namely, first How is the setting of legal sanctions against Notary violating Obligations and Prohibition of UUJN and second, what is the mechanism of handing down sanction (pursuant to the procedural law) to the Notary violating obligations and prohibitions UUJN how is the settlement mechanism of legal sanctions against Notary violating UUJN-P?

This study is qualified as a normative legal research. The source of legal materials for this study was obtained from primary, secondary and tertiary legal materials. The results of this thesis are civil sanction is governed in Article 16 paragraph (9 and 12), Article 41, Article 44 paragraph (5), Article 48 paragraph (3), Article 49 paragraph (4), Article 50 paragraph (5) and Article 51 paragraph (4) of UUJN. The administrative sanction is governed in Article 7 paragraph (2), Article 16 paragraph (11 and 13), Article 17 paragraph (2), Article 19 paragraph (4), Article 32 paragraph (4) Article 37 paragraph (2), Article 54 paragraph (2) and Article 65A of UUJN. Criminal sanctions are not governed, but a notary may be charged with criminal sanction pursuant to the provisions of Penal Code, providing that the act of the notary has complied with the formulation of breaches set forth in the UUJN, ethic codes and Penal Code. Second, the mechanism of application of civil sanction related to the cancellation of authentic deed into under hand deed should go through civil lawsuit process at general court lodged by the parties whose names are stipulated in the deed and suffer from damages as the effect of such deed. The mechanism of application of administrative sanctions to a notary should be directly imposed by the Supervisory Board, where the sanctions are gradually applied. The mechanism of application of criminal sanction to a notary if proved to commit the criminal act, the Notary shall be penalized and generally Penal Code can be applied to the Notary pursuant to the principle of lex spcialist derogate legi generali interpreted in a contrario manner.

Key words: legal sanction, obligation, notary prohibition.

* Mahasiswa Program Studi Kenotariatan T.A 2014/2015.

**Pembimbing I

$* * *$ Pembimbing II 